\title{
Spine Morphology and Plasticity in X-linked Mental Retardations
}

\author{
Jyothi Arikkath*
}

Department of Physiology, 1550 Fourth Street, University of California, San Francisco, San Francisco, California 94143, USA

\begin{abstract}
In the past several years, a multitude of genes has been linked to mental retardations in humans, in particular the most commonly occurring X-linked mental retardations. An emerging idea is that structural and functional abnormalities in spines and synapses are a common feature of mental retardations. Consistent with this concept, a number of genes that control synaptic function have been implicated in X-linked mental retardations. In this review we discuss aberrations in spine and synapse structure and function in X-linked human mental retardations and corresponding mouse models with mutations in genes that modulate synaptic structure and function. A thorough understanding of these synaptic structures and abnormalities would enhance our knowledge of the normal process of learning and understand how synaptic aberrations contribute to cognitive deficits such as those observed in mental retardations.
\end{abstract}

\section{INTRODUCTION}

Mental retardations affect $1-3 \%$ of the population and are characterized by deficiencies in mental functioning and social skills. They are often observed in association with other symptoms in a wide variety of neurological disorders and are diagnosed early in life. Mental retardations vary in severity, however their consequences are devastating and lead to a compromise in the quality of life for the individual.

Both genetic and environmental factors contribute to the etiology of mental retardation. However, it is widely believed that aberrations in synaptic structure and efficacy contribute to the cognitive decline observed in mental retardations $[1,2]$. Consistent with this idea, abnormalities in dendritic and spine structure are observed in a wide variety of mental retardations [3]. Moreover, several genes that control molecular pathways regulating synaptic structure and function have been implicated in mental retardations in humans. Mouse models of several of these genes exhibit anomalies in spine and synapse architecture and deficiencies in learning and memory paradigms, further supporting the strong functional relationship between synaptic structure and higher order brain functions.

Mutations mapping to the X-chromosome are by far the most common forms of mental retardations [4]. In this review we examine molecular insights into spine and synapse abnormalities in some of the X-linked mental retardations associated with mutations in genes that regulate synaptic structure and function.

\section{X-LINKED MENTAL RETARDATIONS}

Mental retardation is more frequently observed in males than in females, with about $30 \%$ more males being affected. $\mathrm{X}$-linked mental retardations account for about $5 \%$ of all mental retardations. X-linked mental retardations are heterogeneous and have been classified into (a) non syndromic

*Address correspondence to this author at the Department of Physiology, 1550 Fourth Street, University of California, San Francisco, San Francisco, California 94143, USA; E-mail: Jyothi.arikkath@ucsf.edu mental retardations in which the mental retardation is the only clinical feature that is consistently observed and (b) syndromic forms of mental retardations in which other abnormalities accompany the mental retardations. To date, almost 90 genes have been linked to X-linked mental retardations [4] and probably several more await identification [5]. Several of these genes regulate multiple aspects of neuronal physiology and function including signaling at the postsynaptic density, transcriptional regulation, protein degradation, exocytosis and endocytosis.

\section{SYNAPTIC STRUCTURE AND PLASTICITY}

During the first years of life, the brain is subjected to intense organization and reorganization of synaptic connections. During this stage, synaptic connections undergo formation, elimination, pruning and remodeling [6]. Synaptic connections are refined throughout development and integrated into neural circuits that ultimately define higher order brain functions, including cognition [7]. Through this period, the brain is also highly vulnerable to the influences of genetic aberrations and environmental insults that can result in abnormalities in synaptic structure and function and subsequently a compromise in higher order brain functions.

Spines are protrusions that arise on dendrites and to the sites of excitatory synapse formation. Eight classes of spines have been identified [8], although the majority of spines in hippocampal neurons are simple with a bulbous head attached via a stalk to the dendrite. The head includes the synaptic structure. Extensive variability is observed in the size, area and volume of the head and length and thickness of the spine neck. Filopodia-like protrusions arise from the dendrite and are widely believed to be the precursors to mature spines. Fig. (1) illustrates the variability in spine morphology observed in cultured rat hippocampal neurons.

The mature synapse is characterized by closely apposed pre and postsynaptic terminals that allow directional information transfer (Fig. 1). The presynaptic machinery consists of neurotransmitter containing vesicles and the machinery to promote vesicle release, while the postsynaptic sites contain receptors that respond to the released neurotransmitter. 

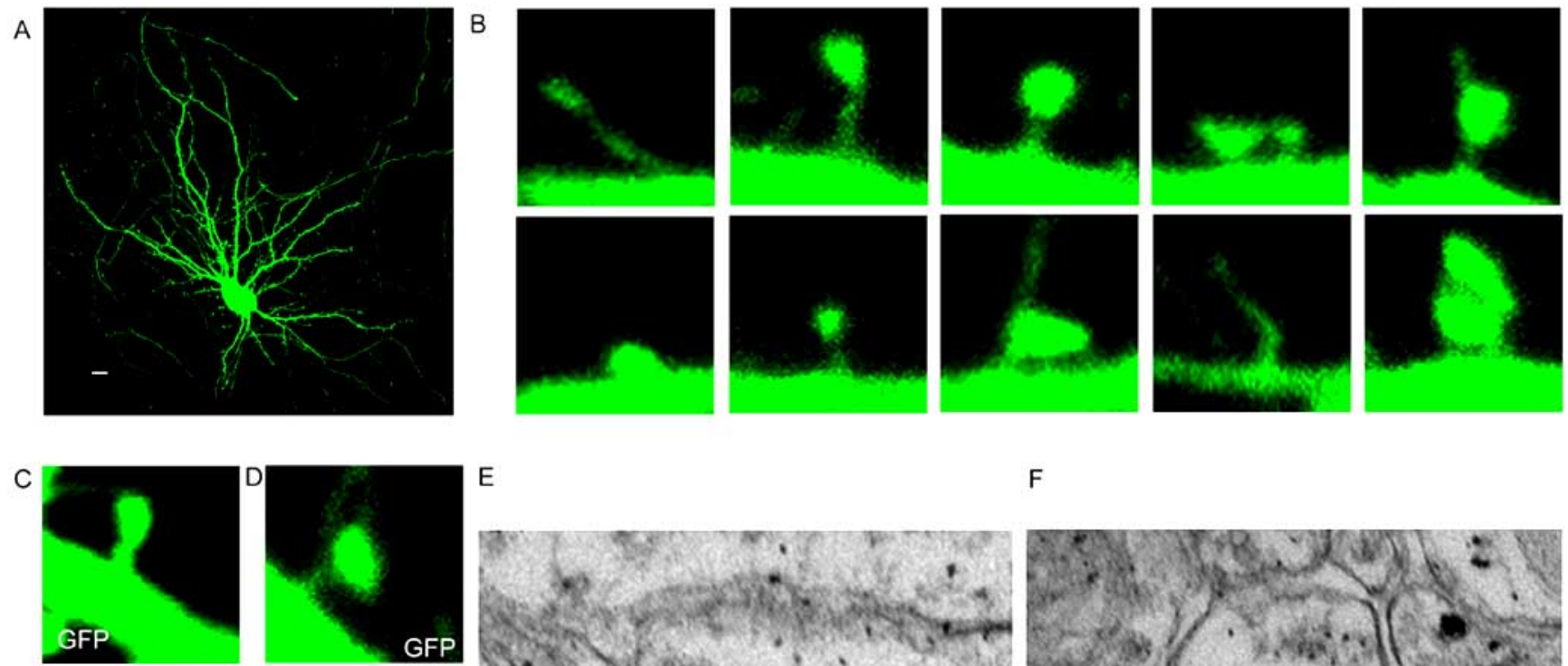

$\mathrm{F}$
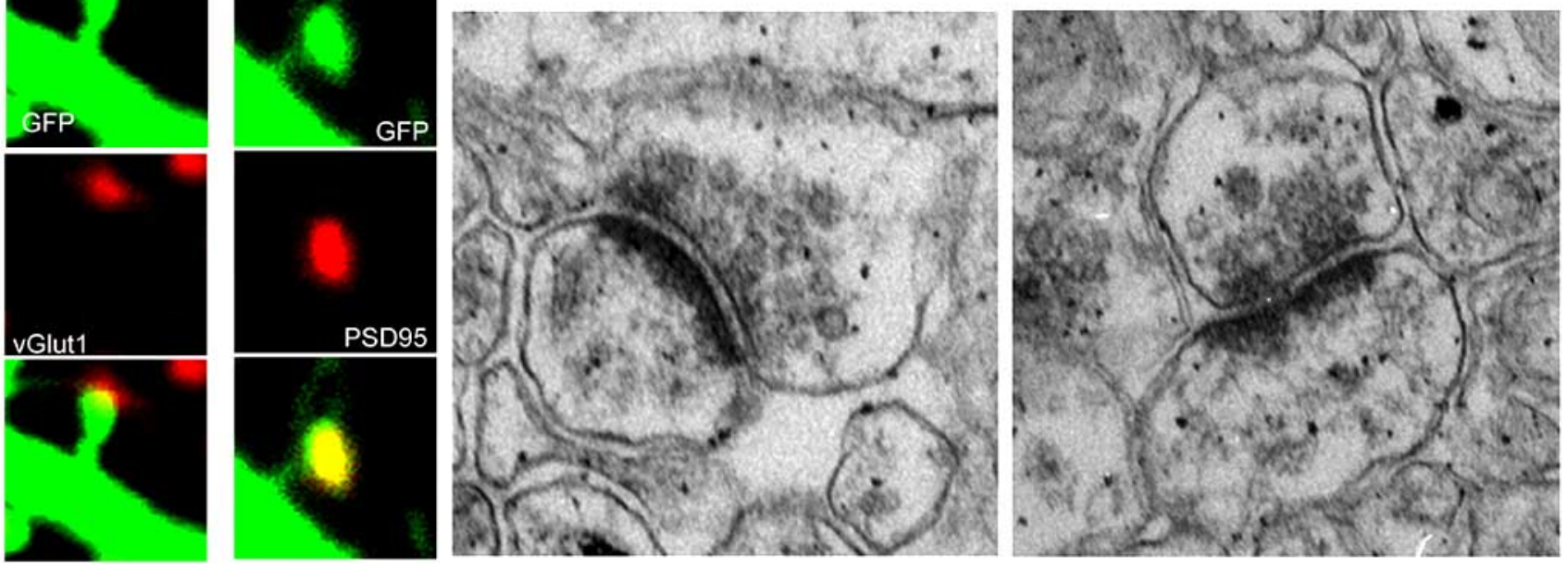

Fig. (1). Spine and synapse morphology

(A) Confocal image of a rat hippocampal neuron in culture (DIV17) expressing green fluorescent protein.

(B) Confocal images of spines from a cultured rat hippocampal neuron (DIV17) expressing GFP. Spines have varied morphology.

(C) Confocal image of a spine from a neuron expressing green fluorescent apposed to a presynaptic terminal as visualized by staining with an excitatory presynaptic marker vGlut1 (red).

(D) Confocal image of a spine from a neuron expressing green fluorescent protein costained with PSD95, an excitatory postsynaptic marker (red).

(E) Electron micrographs of an excitatory synapse from the mouse hippocampus (CA1- stratum radiatum) showing pre and postsynaptic terminals.

(F) Electron micrographs of an excitatory synapse from the mouse hippocampus (CA1- stratum radiatum) showing pre and postsynaptic terminals at a split synapse.

Moreover, spines are highly plastic and respond to physiological cues by alterations in structure and output [9-11]. A wide variety of proteins are necessary to efficiently orchestrate synaptic transmission and plasticity and it is conceivable that any alterations in these molecular pathways could contribute to deficiencies in learning and memory and cognitive disorders.

\section{CONTROL OF SYNAPTIC STRUCTURE AND FUNCTION}

The shape and size of the dendritic tree is important for synaptic structure and function because it determines the nature of the synaptic input and the ability of the neuron to integrate synaptic information [12]. Hence proteins that regulate dendritic arborization can also have significant impact on synaptic structure and function.

Several proteins impact spine and synapse structure directly. These include the (a) Rho family of GTPases (RhoA, Rac1, cdc42) and proteins that regulate the activity of these
GTPases including guanine nucleotide exchange factors and GTPase activating proteins $[13,14]$ (b) the Ras GTPases and the MAP kinase pathway proteins [15] (c) scaffolding proteins [16] (d) cell adhesion proteins [17, 18], cell surface receptors, and (e) regulators of the actin cytoskeleton [19, 20]. Other signaling pathways also converge on these proteins to impact spine structure and function. Multiple signaling events can therefore affect synaptic structure and function, a feature that greatly enhances the ability of spines to be plastic and respond to stimuli.

\section{Genes Regulating Synaptic Structure and Function in X-Linked Mental Retardations}

Genes that underlie X-linked mental retardations control synaptic structure and function at various levels. These include signaling at the postsynaptic density, exoctyosis of presynaptic neurotransmitter vesicles, gene transcription, gene translation and cell adhesion. 


\section{Signaling Molecules}

OPHN-1: OPHN-1 encodes Oligophrenin-1, a Rho GTPase activating protein (Rho GAP) whose loss of function has been implicated in syndromic X-linked mental retardation $[21,22]$. The protein includes a BAR domain (Bin/amphiphysin/Rvs), a pleckstrin homology domain, proline-rich motifs that bind SH3 homology domains and a RhoGAP domain that allows negative regulation of Rac, Rho and cdc42. The Rho family of small GTPases have been linked to various aspects of spine morphogenesis [23]. Oligophrenin-1 is localized pre and postsynaptically in neurons [24].

Mental retardation in humans has been attributed to the duplication disruption, exon deletion, occurrence of nonsense mutations and splice site mutations in OPHN-1 [22, 25-27].

Several different studies using a variety of approaches indicate an important role for oligophrenin-1 in modulating spine and synaptic structure and function. A mouse model that is deleted for the OPHN-1 gene has recently been generated [28]. In the hippocampus of adult mice, loss of oligophrenin-1 does not lead to any alterations in dendritic structure, however it does impact spine structure. Basal dendrites have normal spine densities with reduced spine lengths. Apical dendrites have reduced density of mature mushroom shaped spines with no change in the density of filopodia-like protrusions [28].

In vitro cultured neurons from null mice exhibit an increase in the density of filopodia-like protrusions (DIV 22) [28]. A similar effect is observed when OPHN-1 is deleted in cultured neurons, using flox-cre recombination, at early stages (DIV 2) before spine maturation or late stages (DIV 18) after spine maturation, suggesting that oligophrenin-1 is essential to maintain, not simply form mature spines during the early stages of development.

Other studies have taken an RNAi mediated knockdown approach to selectively address cell autonomous and postsynaptic effects of loss of OPHN-1. Short term (48 hours) RNAi mediated knockdown of oligophrenin in organotypic hippocampal slices leads to a decrease in spine length with no alterations in spine density [24]. Mechanistically, oligophrenin-1 normally functions as a repressor of the RhoA/Rho kinase pathway and its loss results in an activation of Rho kinase and subsequent decrease in spine length caused by alterations in the actin cytoskeleton [24]. Long term knockdown (7 days) leads to a decrease in spine density [29]. Oligophrenin-1, via its GAP, domain also regulates the increase in spine size associated with long term potentiation [29].

Recent studies also indicate a role for oligophrenin-1 in activity dependent maturation and plasticity of excitatory synapses. The localization of oligophrenin-1 to synapses is regulated by synaptic activity and the protein controls the stabilization of AMPA receptors [29]. Loss of oligophrenin1 prevents the maturation of glutamatergic synapses by controlling the number of surface AMPA receptors $[29,30]$ and consequently a reduction in long-term depression.

At the behavioral level, null mice display enhanced activity when exposed to novel environments, but are impaired in spatial learning. These mice also exhibit altered social be- havior, a feature characteristic of human mental retardations. Taken together, it is clear that oligophrenin-1 regulates spine and synaptic structure and function by multiple pathways at various stages during development. Oligophrenin-1 may likely contribute to the cognitive decline observed in mental retardation patients by altering synaptic structure and function.

PAK3: PAK3, p21-activated kinase-3, encodes a serine threonine kinase. Structurally, the protein includes a kinase domain in the $\mathrm{C}$ terminal region, while the $\mathrm{N}$ terminus contains the binding domain for the small GTPases Rac1 and cdc42 [31]. Two other PAK family members, namely PAK1 and PAK2 are also expressed in neurons.

Most human mutations in PAK3 are missense mutations that affect protein function [32]. A truncation of the protein with loss of the kinase domain has also been implicated in non syndromic X-linked mental retardation [33].

A phosphorylated form of PAK, representing an activated state, is localized to synapses and colocalizes with the excitatory marker, PSD95 (post synaptic density 95). Expression of various mutant forms of PAK3 in cultured hippocampal neurons reveal a critical role for PAK3, in particular its ability to function as a kinase, in spine architecture. Overexpression of the wild type PAK3 or a constitutively active form promotes an increase in the density of spines and dendritic protrusions. Conversely the expression of a kinase dead mutant causes a decrease in the density of dendritic spines and synapses as examined by staining with PSD95, suggesting that the kinase activity of PAK3 is critical for its ability to regulate spine structure [34]. One of the downstream effectors of PAK regulating spine morphogenesis is the myosin II regulatory light chain.

In vitro studies provide evidence that at least some of the known human mutations in PAK3 affect spine morphology and function. Knockdown of PAK3 in hippocampal neurons results in the formation of thin long, immature spines with no change in spine density [35]. The expression of a kinase dead (MRX30) mutant known to occur in humans, results in a similar effect. Interestingly, the MRX30 mutation leads to long necked structures with enlarged heads that lack the postsynaptic density or long filopodia like structures that express a small postsynaptic density. Functionally expression of the MRX30 mutant results in a reduction in frequency, but not amplitude, of mEPSCs (miniature excitatory postsynaptic currents) [36]. This is accompanied by a significant decrease in the AMPA/NMDA ratio and impairment in long-term potentiation. Similar structural alterations are observed in hippocampal neurons expressing two other known human mutations in the kinase domain (R419X and A365E) [37]. Another point mutation is located at the $\mathrm{N}$ terminal region $(\mathrm{R} 67 \mathrm{C})$ and inhibits the binding of PAK3 to cdc42 but enhances its affinity for Rac1. In contrast to the expression of the kinase deficient mutants, expression of the $\mathrm{N}$ terminal mutant that has low affinity for cdc 42 results in the reduction of spine density with no obvious alterations in other spine parameters. Clearly the various mutations observed in PAK3 do not give rise to the same phenotype, but all appear to compromise synaptic structure. The data suggest that PAK3 functions in both spine initiation and maturation and indicate that both the kinase and $\mathrm{N}$ terminal regions of PAK3 are functionally important. 
Mice that lack PAK3 have been generated to dissect out its functional role. In contrast to the in vitro studies described above, PAK3 null mice have normal dendritic and synaptic structure [38], possibly due to the compensatory influences of PAK1 and PAK2 [35]. These mice do not show any alterations in basal synaptic strength and neurotransmitter release, however long lasting synaptic plasticity is impaired, specifically hippocampal late long-term potentiation. PAK3 null mice show normal spatial behavior. At the molecular level, loss of PAK3 leads to an increase in the level of Phospho Ser 133-CREB. Interestingly, CREB and Phospho Ser 133-CREB have been implicated in late longterm potentiation suggesting a pathway by which loss of PAK3 may contribute to the pathology of mental retardation.

A mouse model expressing a forebrain specific dominant negative form of PAK has been generated. This protein binds to all 3 PAK isoforms and inhibits their catalytic function [39]. In these mice, spine parameters are affected suggesting an important functional role for PAK proteins. Mutant mice have decreased spine density in the layer II/III of the temporal cortex, but not in the CA1 pyramidal neurons of the hippocampus. Unlike the observations made in mice with mutations in other mental retardation associated genes, including fragile X syndrome, these mice have an increased proportion of short spines with enlarged postsynaptic densities and spine heads in cortical neurons. Again these morphological changes were not observed in the hippocampus. Cortical spine alterations are accompanied by a larger pool of docked presynaptic vesicles, indicating a shift to larger sized synapses. Functionally, these larger synapses have increased amplitude of AMPA mediated mEPSCs. Transgenic mice also have an impaired induction phase of long-term depression and enhanced long-term potentiation. These mice are deficient in consolidation of spatial memory and contextual fear memory [39].

ARHGEF6: ARHGEF6 (also known as $\alpha$ PIX or cool-2) encodes a guanine nucleotide exchange factor for the Rho GTPases [40], Rac1 and cdc42. Structurally the protein includes SH3, a Dbl homology and pleckstrin homology domains with a unique $\mathrm{N}$ terminal calponin homology domain. ARHGEF6 is localized to postsynaptic densities and colocalizes with PSD95 [41].

Human mutations in ARHGEF6 include a gene translocation resulting in gene disruption and exon skipping mutations resulting in a predicted protein that lacks the C-terminal 28 amino acids [40].

Mice that genetically lack ARHGEF6 have not yet been described. However, studies in culture provide some clues to its functional role. Overexpression of ARHGEF6 in organotypic rat hippocampal slices does not alter spine parameters. However siRNA mediated knockdown of ARHGEF6 in these slices results in no change in the density of spines, but profound alterations in spine morphology including a decrease in the number of mushroom spines and an increase in the number of filopodia-like protrusions and elongated spines. ARHGEF6 regulates spine morphology via PAK3 signaling, since a constitutively active form of PAK3 reverses the spine phenotype generated by the knockdown of ARFGEH6 [41].
Given the involvement of ARHGEF6 in familial mental retardation, it would be interesting to examine the effect off loss of ARHGEF6 on spine morphology and synaptic plasticity in a genetically modified mouse model.

RSK2: RSK2 (Ribosomal S6 kinase 2) is a serine/threonine kinase that acts on the Ras/MAPK signaling pathway. The protein structure includes two functional kinase domains connected by a linker region. The linker region includes a docking site for 3-phosphoinositidedependent kinase-1. The protein also includes a docking site for ERK (extracellular regulated kinase). RSK2 has several substrates including ATF4, CREB and histones. RSK2 has been identified as a component of the NMDA receptor multiprotein complex [42].

Several different mutations have been observed in RSK2 in the Coffin-Lowry syndrome including missense mutations, nonsense mutations, splicing errors, deletions, insertions or duplications [43-45]. RSK2 has been implicated in exocytosis in neuroendocrine cells [46, 47], however it is unclear if it is important for exocytosis at other synapses.

RSK2, via its $\mathrm{C}$ terminal region, binds several proteins that contain the PDZ (PSD)95/discs large/ZO-1)domain, including Shank1, Shank3 and GRIP and can phosphorylate Shanks [48]. Several PDZ domain containing proteins regulate spine morphology and plasticity $[49,50]$ and it remains to be determined if any of their functional roles are dependent on their ability to be phosphorylated by RSK2.

Mice that lack RSK2 are impaired in spatial working memory and long term spatial memory deficits and hyper react to environmental changes. RSK2 null mice also have increased cortical levels of dopamine. Since dopamine is critical for different kinds of behavioral effects, it is possible that some of the behavioral deficits observed in null mice can be attributed to the effects of dopamine [51]. The status of spines and synapses in the cortical and hippocampal regions of the brain remain to be investigated.

\section{Presynaptic Vesicle Assembly and Cycling}

GDI1: GDI1 (Rab GDP dissociation inhibitor) encodes a protein that controls the activity of the Rab GTPase family of proteins in vesicle fusion and intracellular trafficking. Two families affected by X-linked non-syndromic mental retardation harbor mutations in GDI1. One of these mutations is a null mutation, while the other one represents a substitution that impairs the recycling of Rab3a [52].

Mice that lack GDI1 have been generated and show deficiencies in hippocampal dependent short-term memory and fear conditioning. Interestingly these mice show impairments in social behavior, a feature that is observed in human mental retardations.

At the molecular level, it has been suggested that the loss of GDI1 leads to deficiencies in presynaptic vesicle cycling [53]. Presynaptic terminals in mice that lack GDI1 have reduced levels of reserve pool synaptic vesicles and show a reduced rate of recovery of synaptic vesicles after depletion [54]. The status of spines and synapses in the mouse model remain unexplored.

OPHN-1: In addition to its postsynaptic function, OPHN1 is presynaptically localized and interacts with proteins that 
participate in the different steps of clathrin mediated endocytosis including ampiphysins, CIN85 and endophilins [30, 55]. Consistent with the role of OPHN-1 in endocytosis, neurons from mice that lack OPHN-1 have deficits in synaptic vesicle recycling.

Similar results are observed with in vitro studies using RNAi mediated knockdown of OPHN-1, suggesting that these effects are cell autonomous [55]. Importantly, the latter study also showed that OPHN-1 mutants defective in endophilin A1 binding, or with impaired Rho-GAP activity, fail to substitute for wild type OPHN-1, indicating that OPHN1 's interactions with endophilin A1 and Rho GTPases are important for its function in synaptic vesicle retrieval. Electrophysiological analysis of synaptic transmission properties in the hippocampus of OPHN-1 null mice shows reduced paired pulse facilitation consistent with altered neurotransmitter release [28]. Together, these data suggest that presynaptic deficits may also contribute to the pathogenesis of OPHN-1 linked cognitive impairment.

\section{Transcriptional and Translational Control}

MeCP2: MeCP2 encodes an X-linked methyl CpG binding protein 2 that binds $\mathrm{CpG}$ nucleotides and represses transcription. Recent studies indicate that it can also function as an activator of transcription [56]. In addition to its methyl $\mathrm{CpG}$ binding domain (MBD), the protein includes a transcriptional repressor domain (TRD). It is predominantly localized to neuronal nuclei and is well expressed during synaptogenesis [57].

Over 200 mutations in this gene including missense, insertions, deletions, splice site variations, frameshift and nonsense mutations have been observed in patients with Rett Syndrome [58]. These mutations are often associated with loss of function. Rett syndrome is a fairly common X-linked mental retardation syndrome that affects $1: 10,000$ to 1:20,000 births. Patients with Rett Syndrome exhibit normal development of behavioral and social skills till the age of 618 months, when they begin to demonstrate regression of social and cognitive skills.

Morphological analysis of postmortem human brains from Rett syndrome patients reveals lack of neuronal cell loss, but smaller neuronal somata and nuclei sizes and overall brain size, reduced dendritic branching accompanied by a reduction in the density of dendritic spines in cortical and hippocampal neurons $[59,60]$. The levels of the synaptic marker synaptophysin have been examined in patients with Rett syndrome by two groups and show a decrease in the motor, frontal and temporal cortices [61] or no difference in the frontal cortex and cerebellum [62].

Several mutant mice have been generated in an attempt to understand the physiological role of MeCP2. Mice that have an in frame deletion of exon 3 (MeCP2J) [63] or deletions of exons 3 and 4 (MeCP2B) of MeCP2 [64] have been well studied. MeCP2B mice have no detectable mRNA or protein of $\mathrm{MeCP} 2$ while the existence of a transcript of MeCP2 in the cerebellum [65] and low molecular weight forms of $\mathrm{MeCP} 2$ have been documented [63] in the MeCP2J strain.

Both strains of mice that lack MeCP2 have abnormalities, including reduced brain size and weight and smaller central nervous system neuronal somata and nuclei sizes and severe dendritic and synaptic abnormalities including reduced dendritic complexity [63], presynaptic function and synaptic plasticity [66] thus recapitulating some of the symptoms observed in patients with Rett syndrome [58, 63, 64].

The status of dendritic spines in these mice is somewhat less clear. A comparative study of 3 week old the MeCP2B and MeCP2J mice revealed regional differences in spine density and structure. The spine density in the fascia dentata is significantly decreased in $\mathrm{MeCP} 2 \mathrm{~B}$, but not $\mathrm{MeCP} 2 \mathrm{~J}$ mice [67], however in CA1 pyramidal neurons spine density is reduced in both strains of mice. In motor cortex layer II/III neurons, spine density is reduced in $\mathrm{MeCP} 2 \mathrm{~B}$, but not $\mathrm{MeCP} 2 \mathrm{~J}$ mice. In general, the $\mathrm{MeCP} 2 \mathrm{~B}$ mice have a more severe loss of spines than the MeCP2J mice. Dendritic spine morphology is also altered in both mutants and showed a significant decrease in head size in layers II/III of the motor cortex and CA1 region of the hippocampus. Further both mutants show an increase in spine length and some lengths of dendrites that are devoid of spines. Another group reported a reduction in dendritic complexity in layer II/III pyramidal neurons in mice that are heterozygous for MeCP2B and $\mathrm{MeCP} 2 \mathrm{~J}$, with no differences in spine density [68]. Another group observed a reduction in spine density at 6 weeks of age in male heterozygous MeCP2b mice in layer II/III of the somatosensory cortex [69]. Further, in 2 week old mutant heterozygous mice presynaptic terminal appears to attach directly to the dendritic structure, as opposed to the spine, and show characteristics of immature postsynaptic densities in layer II/II of the somatosensory cortex.

Loss of MeCP2 has effects on both excitatory and inhibitory transmission and results in an imbalance on the excitatory - inhibitory ratio. МeCP2B mice have reduced GABAergic but not glycinergic neurotransmission in the ventrolateral medulla. This phenotype arises from a reduction in GABAergic release and from alterations in postsynaptic GABA receptors [70]. Adult MeCP2J mice also have reduced levels of the postsynaptic excitatory marker PSD95 in the motor cortex accompanied by a decrease in the excitatory postsynaptic currents and reduced number of spines in the hippocampus, suggesting a reduction in excitatory synapse density [71]. In addition, these mice have enhanced cortical plasticity in the visual cortex.

Mice that express a truncated form of MeCP2 $\left(\mathrm{MeCP}^{308}\right)$ similar to that observed in some human mutations have also been generated. This form of MeCP2 lacks the $\mathrm{C}$ terminal region but includes the $\mathrm{N}$ terminal $\mathrm{MBD}$, TRD and nuclear localization signals [72]. $\mathrm{MeCP}^{308}$ mice have behavioral and learning abnormalities including deficits in spatial memory, contextual fear memory and social memory. These mice do not show abnormalities in dendritic arbors or biochemical composition of synapses in the hippocampus. However postsynaptic densities have reduced length with no change in the number of presynaptic vesicles. These mice exhibit enhanced neurotransmitter release, but deficits in long term potentiation [73].

Mice that overexpress the human $\mathrm{MeCP} 2$ at about twice the wild type levels have augmented motor and contextual learning and display increased hippocampal synaptic plasticity [74]. These changes are accompanied by an increase in synaptic density in vivo [75]. 
In vitro studies on cultured autaptic neurons from mice that lack MeCP2 or overexpress MeCP2 revealed that loss of $\mathrm{MeCP} 2$ results fewer glutamatergic autapses and function while the opposite effect is observed in neurons that overexpress MeCP2. This study contrasts other studies done in high density cultures, [76] which showed a reduction in the frequency of mEPSCs with no alterations in synapse density. Autapses in micro-island neuron cultures develop differently than synapses between different neurons in cultures at higher cellular density $[77,78]$, which may explain the observed differences.

Numerous studies in vitro have been carried out to ascertain the functional roles of MeCP2 and its disease causing variants. Expression of $\mathrm{MeCP} 2$ harboring mutations observed in Rett syndrome in organotypic rat hippocampal slice preparations results in a persistent decrease in mature spine density. Intriguingly, overexpression of $\mathrm{MeCP} 2$ has a similar effect [60], but this is transient.

In vitro studies in cultured rat hippocampal neurons have shown that knockdown of MeCP2 results in a simplification of dendritic trees [79]. Interestingly, overexpression of $\mathrm{MeCP} 2$ has a similar effect on dendritic branching indicating that the level of MeCP2 in neurons is critical. This ability of $\mathrm{MeCP} 2$ to regulate dendritic growth is critically dependent on its ability to be phosphorylated at S421, since a mutation at this residue to alanine inhibits the ability of MeCP2 to regulate dendritic branching when overexpressed [80]. The phosphorylation of this residue is activity dependent, suggesting that $\mathrm{MeCP} 2$ is critical for activity induced alterations in dendritic arborization.

MeCP2 also affects spine morphology, although it does not have any effect on spine density in cultured neurons. Knockdown of MeCP2 does not alter spine morphology, however overexpression of $\mathrm{MeCP} 2$ results in longer, thinner spines resembling immature spines. This effect is not observed with the S421 mutant of MeCP2. Hence activity dependent phosphorylation of $\mathrm{MeCP} 2$ at $\mathrm{S} 421$ regulates both dendrite arborization and spine maturation [80]. Physiologically, the S421 residue in MeCP2 can be phosphorylated by the activity of CaMKII in response to activity induced calcium influx. MeCP2 also regulates the transcription of $\mathrm{BDNF}$ in an S421 phosphorylation dependent manner. BDNF has been shown to regulate dendritic and spine architecture in a variety of neuronal cell types $[81,82]$.

Overall, current evidence supports the idea that the levels of cellular $\mathrm{MeCP} 2$ are critical for its normal physiological function and loss of $\mathrm{MeCP} 2$ function impairs excitatory synapse formation or exacerbates excitatory synapse pruning, potentially affecting glutamatergic synaptic transmission and/or plasticity in a brain region-specific manner. The repertoire of genes that are regulated by MEPC2 is under intense investigation [83]. However several candidate genes have been described including BDNF [84, 85], -1, Leukosialin, DLX-5, Crh and FXYD1 [86], of which both BDNF and FXYD1 are known to impact spine morphogenesis. Further studies are necessary to delineate the target genes of $\mathrm{MeCP} 2$ that regulate synaptic structure and plasticity. Clearly MeCP2 is a key transcriptional regulator that allows neurons to convert activity dependent cues to selective patterns of genes expression that ultimately drive proper neuronal development, cytoarchitecture and plasticity.
FMR1: The FMR1 gene encodes an RNA binding protein, the fragile $\mathrm{X}$ mental retardation protein (FMRP). Fragile $\mathrm{X}$ syndrome arises as a result of loss of function of the FMR1 gene [87, 88]. The 5' UTR of FMR1 is vulnerable to a triplet nucleotide repeat expansion. An expansion of more than 200 repeats is observed in individuals with the fragile $X$ syndrome, characterized by mental retardation and autistic behavior and pathology. Functionally such mutations result in loss of function.

FMRP has been suggested to suppress translation [89] and regulate transport of mRNA [90] and, more recently, to activate translation [91]. FMRP also serves to stabilize some mRNAs [92]. In neurons FMRP is primarily localized to the cytosol and in cell soma, dendrites, base of synaptic spines and in axons [93-96]. Structurally, the protein includes two hnRNP-K homology domains and an RGG (arginine glycine rich RNA binding motif) domain and a novel RNA binding domain in the $\mathrm{N}$ terminus. FMRP co-sediments with the large polyribosome complexes as well as with mRNPs [97] and it has been suggested to be important for regulating dendritic mRNA metabolism and in particular synaptic protein expression [98]. A number of mRNAs (ranging from $400-$ 600), including its own mRNA, bind to FMRP [88]. Several target mRNAs of FMRP are known including PSD95, Microtubule Associated Protein 1b (Map1b), Activity regulated cytoskeletal protein (Arc / Arg 3.1), APP (amyloid precursor protein), AMPA receptor subunits GluR1 and GluR2 and $\alpha$ CamKII. Presumably many more remain to be identified [90].

A number of studies have examined the morphology of spines and dendrites in patients afflicted by the disease and have found evidence of abnormal spine morphology. In general, spines in patients show a thinner and longer appearance reminiscent of filopodia in the neocortex and temporal and visual cortices accompanied by an increase in spine density [99-101] suggesting that spine elimination and maturation may be affected in this disease [102].

The structure and function of spines and synapses have been examined in mouse models that lack FMRP. Though these studies have been somewhat complicated by the differences observed in mice from different backgrounds, they do support the existence of spine abnormalities in a region and age dependent manner. In the first Fmr1 null mice that were generated, spine length and density were both increased in the visual cortex [103]. However, the interpretation of these results has been complicated by the fact that the mice examined were homozygous for a gene that causes retinal degeneration, raising the possibility that some of the spine deficits observed in the visual cortex may have been independent of the loss of FMRP. However similar spine morphology has also been observed in the visual cortex [104], hippocampus [105] and cerebellum [106]of another FMRP null mouse model suggesting that immature spine morphology is a feature of loss of FMRP.

Some studies suggest that the immature spine phenotype in mice that lack FMRP is transient. Two photon imaging in mice that express GFP and lack FMRP, has shown that loss of FMRP leads to an increase in spine length and density in the barrel cortex. However this effect is only observed at postnatal days 7 and 14 and is resolved by postnatal day 28 , 
indicating that spine and synapse development may be delayed [107].

In vitro studies in cultured neurons from FMRP null mice show morphologies that are different from in vivo studies. In contrast to the in vivo studies, cultured neurons from FMRP null mice have fewer and smaller spines. Functionally they also have fewer synaptic connections [108]. However, overexpression of FMRP in cultured hippocampal neurons leads to a decrease in synaptic number without affecting their maturity [109]. Recently the immature looking phenotype observed in vivo has been documented in primary neuronal cultures by at least three groups [110-112]

Synaptic plasticity is also altered in mice that lack FMRP. FMRP null mice have reduced cortical plasticity [113]. Hippocampal long term potentiation has been reported to be unchanged [114] or reduced [115]. mGluR and protein synthesis dependent long term depression is enchanced in mice that lack FMRP [116] and is consistent with the hypothesis that misregulation of mGluR protein synthesis may contribute to the pathology of fragile X syndrome [117].

A new mouse model that lacks both the Fmr1 transcript and the FMRP protein has been generated and should prove to be a valuable model to study the effects of loss of FMRP [118]. In these mice, the ratio of postsynaptic AMPA/NMDA shows developmental differences with a large reduction in the ratio at $\mathrm{P} 14$, but not at 6-7 weeks of age. These changes are accompanied by a reduction in the protein level ratio of AMPA/NMDA. There is also a reduction in the amplitude, but not frequency, of mEPSCs mediated by AMPA receptors. The null mice also display an increase in long term potentiation in the hippocampus during development, but these changes are not observed at later stages, suggesting that glutamatergic transmission is affected only during development.

Recent studies also indicate a presynaptic functional role for FMRP. FMRP localization has been observed in axons and axonal growth cones in hippocampal neurons [95], primary afferent neurons of the dorsal root and trigeminal ganglia [94] and in striatal neurons [119]. Using neurons from chimeric mice that are mosaic for the expression of FMRP, it has recently been shown that presynaptic loss of FMRP leads to a decrease in synaptic connections to neighboring neurons in the CA3 region of the hippocampus [120]. This is consistent with a cell autonomous presynaptic functional role for FMRP. Taken together it is clear that FMRP regulates synaptic structure and function by several mechanisms.

A molecular basis of therapy would clearly be advantageous to improve the quality of life of fragile $\mathrm{X}$ patients. Some progress has recently been made in this regard. Genetic reduction of the level of mGlurR5 in Fmr1 null mice alleviates many of the symptoms observed in Fmr1 null mice, including the spine density [121]. Recent studies have taken advantage of viral assisted techniques to restore the FMRP in adult hippocampal neurons in mice that lack FMR1 with encouraging results. Restoration of FMRP rescues the paired pulse facilitation induced enhanced mGluR long term depression [122]. These studies are promising for human treatments since they suggest that restoration of FMRP after development may still be therapeutic for the treatment of cognitive disorders associated with loss of FMR1.
UPF3B: UPF3B is a component of the nonsense mediated decay complex, a complex that mediates degradation of mRNAs with premature termination codons. Mutations in UPF3B have been recently described in families with LujanFryns syndrome and non syndromic mental retardation [123] and result in loss of protein or protein truncations.

In hippocampal neurons, UPF3B is expressed in the cytoplasm, at spines and in nuclei. The functional role of UPF3B in spine architecture and plasticity, in particular in a murine model, is unclear. Expression of UPF3B with two different amino acid substitution mutations (Arg379His and Arg368Gln) observed in humans do not cause any obvious alterations in spine morphology [124].

\section{Cell Adhesion Molecules}

\section{Neuroligin 4}

The neuroligin family of proteins mediate cell adhesion and structurally have a single transmembrane domain, a cholinesterase like domain, a carbohydrate attachment domain and an intracellular region with a PDZ binding motif [125] (see review by Vicente-Manzanares et al., this volume).

Neuroligins are highly expressed at synapses and mediate their functional roles through binding neurexins, a family of single transmembrane domain containing proteins that is extensively alternatively spliced. The PDZ binding motifs of neuroligins mediate its interaction with a variety of PDZ domain containing proteins, including PSD95, S-SCAM, SAP102, SPAR, Shank and Pick1. Neuroligin 1 and 2 are exclusively associated with excitatory and inhibitory synapses respectively, while neuroligin 3 is localized to both types of synapses [126, 127].

Neuroligins 1-3 have been extensively studied in neurons, however the characterization of neuroligin 4 is relatively less complete. Similar to the expression of the other neuroligins, the expression levels of neuroligin 4 are low during early postnatal life and plateau at 3 weeks of age and are maintained in the adult. Similarly, neuroligin 4 is enriched in synaptic membrane fractions [128], suggesting that it may have a similar functional role.

In vitro studies indicate that neuroligins promote the development of inhibitory and excitatory synapses and the expression levels and localization of neuroligins can influence the excitatory/inhibitory ratio in neurons [125]. However, in vivo studies in genetically modified mouse models suggests that neuroligins are not necessary for synapse formation, but are essential for synaptic function since mice that lack either neuroligin have apparently normal synaptic ultrastructure but deficiencies in synaptic transmission [129].

Mutations in NLGN4X, the gene encoding neuroligin 4, have recently been implicated in non syndromic mental retardation [130]. Mutations include a deletion that results in a premature stop codon (429X) and a base pair substitution in the promoter region resulting in enhanced expression of the gene [131]. Previously mutations in NLGN3 and 4 have been implicated in some forms of autism, suggesting that mental retardations and autism spectrum disorders may have some common origin. In humans neuroligin 4 on the $\mathrm{X}$ chromosome is complemented by neuroligin 5 on the $\mathrm{Y}$ chromosome [132]. 
A mouse model that lacks neuroligin 4 has recently been generated in an effort to understand the contribution of this gene to the pathology of autism and mental retardation. At the molecular level, the loss of neuroligin 4 does not lead to any detectable alteration in the expression of the other neuroligins. Comparable to the effect of loss of other neuroligins on synaptic transmission, loss of neuroligin 4 leads to selective deficiencies in glutamatergic synaptic transmission [128]. The effect of loss of neuroligin 4 on spine architecture remains to be examined.

At the behavioral level, neuroligin 4 null mice do not have any detectable alterations in vision, olfaction, taste, hearing, locomotor activity, anxiety, learning and behavior and cognitive flexibility. However they do exhibit deficiencies in social interaction and communication [128].

Further studies are necessary to assess the extent of contribution of loss or mutations in neuroligin 4 to the pathology of mental retardation. Table 1 provides a brief summary of the spine abnormalities associated with various X-linked mental retardations. Fig. (2) shows a neuron expressing green fluorescent protein that outlines the cell and stained with a nuclear marker. In addition, the structure of an excitatory synapse with the localization and functional roles of some of the proteins discussed in this review are also depicted.

Table 1. Summary of the Characteristics of Spines Observed in Various Models of X-Linked Mental Retardations Associated with Mutations in Synaptic Proteins

\begin{tabular}{|c|c|c|c|c|c|c|}
\hline Disease & Gene & Gene Function & Locus & $\begin{array}{l}\text { Mutations in } \\
\text { Humans }\end{array}$ & Model System & $\begin{array}{l}\text { Spine / Synapse } \\
\text { Morphology }\end{array}$ \\
\hline \multicolumn{7}{|l|}{ Signalling Proteins } \\
\hline \multirow{3}{*}{$\begin{array}{l}\text { Syndromic } \mathrm{X} \text { linked } \\
\text { mental retardation }\end{array}$} & \multirow{3}{*}{ OPHN1 } & \multirow{3}{*}{$\begin{array}{l}\text { RhoGTPase } \\
\text { activating protein }\end{array}$} & \multirow{3}{*}{$\mathrm{Xq} 12$} & \multirow{3}{*}{$\begin{array}{l}\text { Duplication, } \\
\text { disruption, exon } \\
\text { deletion, nonsense } \\
\text { mutations, splice } \\
\text { site mutations }\end{array}$} & Null mouse -adult & $\begin{array}{c}\text { Basal dendrites have re- } \\
\text { duced spine lengths, apical } \\
\text { dendrites - reduced spine } \\
\text { density [28] }\end{array}$ \\
\hline & & & & & $\begin{array}{l}\text { RNAi mediated } \\
\text { knockdown (acute - } \\
\text { 48hours) - organo- } \\
\text { typic rat cultures }\end{array}$ & $\begin{array}{l}\text { Decreased spine length, no } \\
\text { effect on density of spines or } \\
\text { filopodia, prevents synapse } \\
\text { maturation [24] }\end{array}$ \\
\hline & & & & & $\begin{array}{l}\text { RNAi mediated } \\
\text { knockdown (chronic } \\
-7 \text { days)- organo- } \\
\text { typic rat cultures }\end{array}$ & $\begin{array}{c}\text { Decrease in spine density } \\
{[29]}\end{array}$ \\
\hline \multirow{5}{*}{$\begin{array}{c}\text { Non-syndromic X } \\
\text { linked mentalretar- } \\
\text { dation }\end{array}$} & \multirow{5}{*}{ PAK3 } & \multirow{5}{*}{$\begin{array}{l}\text { Serine threonine } \\
\text { kinase }\end{array}$} & \multirow{5}{*}{$\mathrm{Xq} 21.3$} & \multirow{5}{*}{$\begin{array}{l}\text { Missense muta- } \\
\text { tions, truncation } \\
\text { mutations }\end{array}$} & $\begin{array}{l}\text { Overexpression - } \\
\text { wild cultured neu- } \\
\text { rons }\end{array}$ & $\begin{array}{c}\text { Increase in spine density } \\
{[34]}\end{array}$ \\
\hline & & & & & $\begin{array}{l}\text { RNAi knockdown - } \\
\text { cultured neurons }\end{array}$ & $\begin{array}{l}\text { Long thin immature spines, } \\
\text { no change in spine density } \\
\text { [35] }\end{array}$ \\
\hline & & & & & $\begin{array}{c}\text { Kinase deficient } \\
\text { mutant expression - } \\
\text { MRX30, R419X and } \\
\text { A365E - cultured } \\
\text { neurons }\end{array}$ & $\begin{array}{l}\text { Long thin immature spines, } \\
\text { no change in spine density } \\
\text { [37] }\end{array}$ \\
\hline & & & & & $\begin{array}{l}\text { R67C (inhibits bind- } \\
\text { ing to cdc42, but } \\
\text { increased affinity for } \\
\text { Rac1)mutant expres- } \\
\text { sion - cultured neu- } \\
\text { rons }\end{array}$ & $\begin{array}{l}\text { Reduction of spine density } \\
{[37]}\end{array}$ \\
\hline & & & & & $\begin{array}{l}\text { Dominant negative } \\
\text { PAK }\end{array}$ & $\begin{array}{c}\text { Cortex- decreased spine } \\
\text { density, increased proportion } \\
\text { of short spines with longer } \\
\text { psd and large spine head } \\
\text { Hippocampus - no obvious } \\
\text { changes in spine structure } \\
\text { [39] }\end{array}$ \\
\hline
\end{tabular}


Table 1. contd....

\begin{tabular}{|c|c|c|c|c|c|c|}
\hline Disease & Gene & Gene Function & Locus & $\begin{array}{l}\text { Mutations in } \\
\text { Humans }\end{array}$ & Model System & $\begin{array}{l}\text { Spine / Synapse } \\
\text { Morphology }\end{array}$ \\
\hline \multirow[b]{2}{*}{$\begin{array}{l}\text { Non syndromic X } \\
\text { linked mental re- } \\
\text { tardation }\end{array}$} & \multirow[b]{2}{*}{ ARGHEF6 } & \multirow[b]{2}{*}{$\begin{array}{l}\text { Guanine nucleo- } \\
\text { tide exchange } \\
\text { factor for } \\
\text { RhoGTPases }\end{array}$} & \multirow[b]{2}{*}{$\mathrm{Xq} 26$} & \multirow[b]{2}{*}{$\begin{array}{l}\text { Gene disruption, } \\
\text { exon skipping }\end{array}$} & $\begin{array}{l}\text { Overexpression in rat } \\
\text { organotypic cultures }\end{array}$ & $\begin{array}{l}\text { No change in spine parame- } \\
\text { ters }[41]\end{array}$ \\
\hline & & & & & $\begin{array}{l}\text { RNAi knockdown in } \\
\text { organotypic rat cul- } \\
\text { tures }\end{array}$ & $\begin{array}{l}\text { No change in spine density, } \\
\text { decrease in number of } \\
\text { mushroom spines, increase } \\
\text { in number of filopodia and } \\
\text { elongated spines [41] }\end{array}$ \\
\hline $\begin{array}{l}\text { Coffin-Lowry } \\
\text { syndrome }\end{array}$ & RSK2 & $\begin{array}{l}\text { Serine threonine } \\
\text { kinase that acts on } \\
\text { Ras/MAPK sig- } \\
\text { naling pathway }\end{array}$ & $\mathrm{Xp} 22.2$ & $\begin{array}{l}\text { Missense muta- } \\
\text { tions, nonsense } \\
\text { mutations, splic- } \\
\text { ing errors, dele- } \\
\text { tions, insertions, } \\
\text { duplications }\end{array}$ & Null mice & Spine structure unknown \\
\hline
\end{tabular}

Presynaptic Vesicle Assembly and Cycling

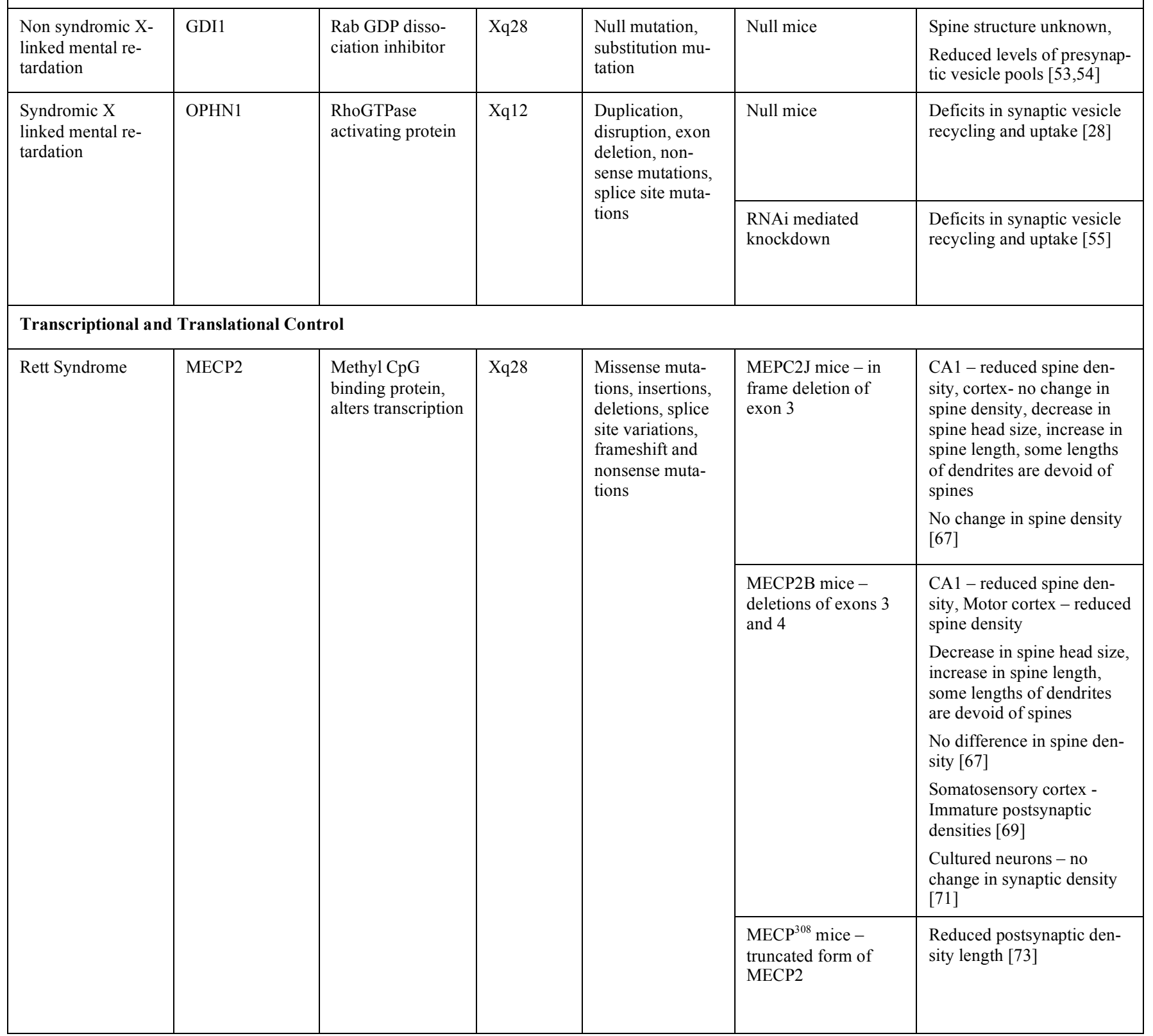


Table 1. contd....

\begin{tabular}{|c|c|c|c|c|c|c|}
\hline Disease & Gene & Gene Function & Locus & $\begin{array}{c}\text { Mutations in } \\
\text { Humans }\end{array}$ & Model System & $\begin{array}{c}\text { Spine / Synapse } \\
\text { Morphology }\end{array}$ \\
\hline & & & & & $\begin{array}{l}\text { Overexpression of } \\
\text { MECP } 2 \text { - mouse } \\
\text { model autaptic cul- } \\
\text { tures }\end{array}$ & $\begin{array}{l}\text { Increase in glutamatergic } \\
\text { synapse number }\end{array}$ \\
\hline & & & & & $\begin{array}{l}\text { RNAi mediated } \\
\text { knockdown - disso- } \\
\text { ciated rat hippocam- } \\
\text { pal neurons }\end{array}$ & $\begin{array}{l}\text { No change in spine mor- } \\
\text { phology }[80]\end{array}$ \\
\hline & & & & & $\begin{array}{l}\text { Overexpression of } \\
\text { MECP2 }\end{array}$ & $\begin{array}{l}\text { Longer and thinner spines } \\
{[80]}\end{array}$ \\
\hline \multirow[t]{2}{*}{$\begin{array}{l}\text { Fragile X syn- } \\
\text { drome }\end{array}$} & \multirow[t]{2}{*}{ FMR1 } & \multirow[t]{2}{*}{$\begin{array}{l}\text { RNA binding } \\
\text { protein, regulates } \\
\text { translation and } \\
\text { transport of } \\
\text { mRNA }\end{array}$} & \multirow[t]{2}{*}{$\mathrm{Xq} 27.3$} & \multirow[t]{2}{*}{$\begin{array}{l}5 \text { 'UTR trinucleo- } \\
\text { tide expansion }\end{array}$} & Null mice & $\begin{array}{l}\text { Increase in spine length and } \\
\text { density }[103,104,105] \\
\text { Transient immature spines - } \\
\text { only observed P7 to P14, } \\
\text { resolved by P28 [107] }\end{array}$ \\
\hline & & & & & $\begin{array}{l}\text { Overexpression - } \\
\text { cultured neurons }\end{array}$ & $\begin{array}{l}\text { Decrease in spine number } \\
\text { [109] }\end{array}$ \\
\hline $\begin{array}{l}\text { Lujan-Fryns syn- } \\
\text { drome and non } \\
\text { syndromic mental } \\
\text { retardation }\end{array}$ & UPF3B & $\begin{array}{l}\text { Component of } \\
\text { nonsense medi- } \\
\text { ated decay com- } \\
\text { plex }\end{array}$ & $\mathrm{Xq} 24$ & $\begin{array}{l}\text { Truncation or } \\
\text { loss of function } \\
\text { mutations }\end{array}$ & $\begin{array}{l}\text { Expression of UFP3B } \\
\text { with mutations } \\
\text { (Arg379His and } \\
\text { Arg368Gln) - cul- } \\
\text { tured neurons }\end{array}$ & $\begin{array}{l}\text { No detectable changes in } \\
\text { spine morphology [124] }\end{array}$ \\
\hline \multicolumn{7}{|l|}{ Cell Adhesion } \\
\hline
\end{tabular}

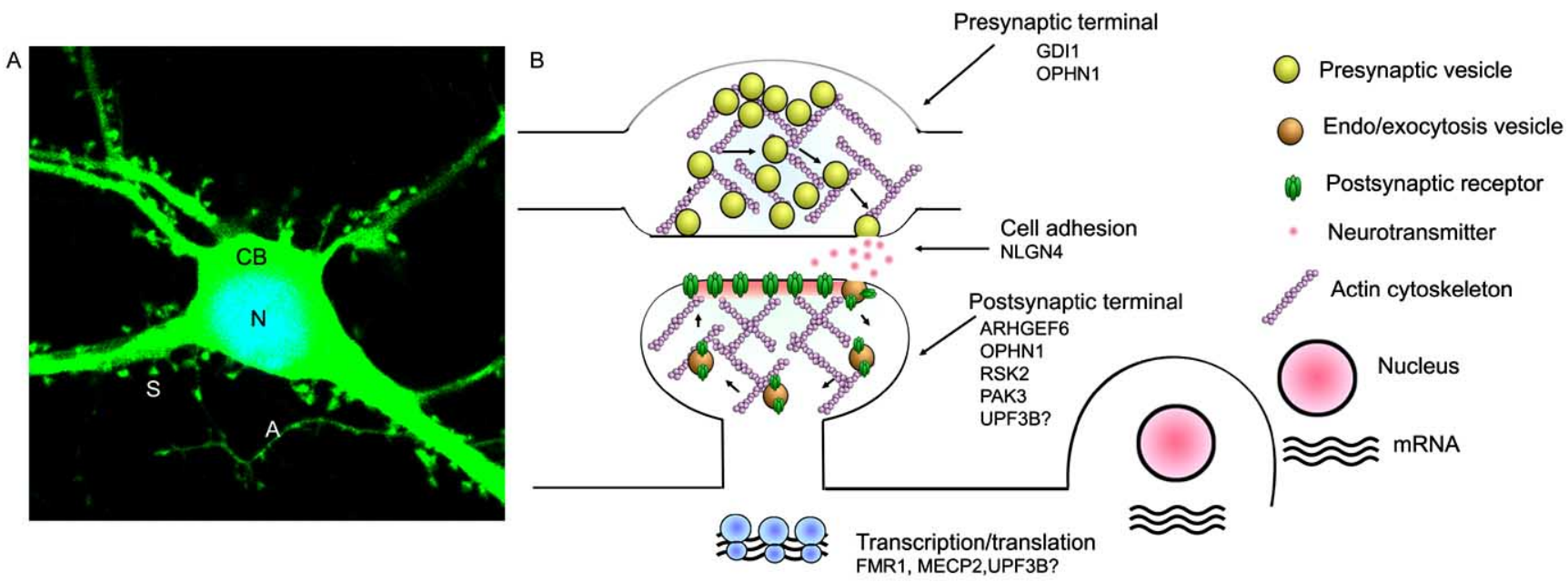

Fig. (2). Localization of proteins linked to X-linked mental retardation.

(A) A confocal image of a rat hippocampal neuron in culture expressing green fluorescent protein that outlines the spine (S), axon (A) and cell body $(\mathbf{C B})$ and counterstained to visualize the nucleus $(\mathrm{N})$.

(B) A schematic of the neuron with pre and postsynaptic terminals, cell body and nucleus showing the functional localization of various proteins implicated in X-linked mental retardation. Some of the genes that have been implicated in X-linked mental retardation affect synaptic structure and function by regulating signaling, vesicle recycling, cell adhesion, transcription or translation. 


\section{Other Genes}

Several other genes that may have synaptic functional roles, including FMR2 [133] (see article by Deng and Dunaevsky, this volume), have been implicated in X-linked mental retardation [56]. However their contribution remain less well characterized. Some of these include, GRIA3 (encoding Glur3) [134], IL1RAPIL [135], DLG3 [136], synaptophysin and CASK [5].

\section{CONCLUSIONS AND FUTURE DIRECTIONS}

The ability of spines and synapses to maintain their architecture and modify it in response to synaptic activity is vital for the normal function of neural networks. Both the pre and the postsynaptic terminals include extensive signaling and scaffolding networks that work in concert to ensure appropriate spine structure and dynamics. Structural and functional abnormalities in synaptic structure and function appear to be a common theme underlying various mental retardations and very likely contribute to the characteristic cognitive decline observed in these patients.

Mutations in several genes that regulate synaptic structure and plasticity have been implicated in both X-linked and non X-linked mental retardations and it is very likely that many more such genes remain to be characterized. Not surprisingly, some of the genes described in this review, OPHN-1, PAK3 and ARHGEF6, regulate synaptic architecture via the Rho family of small GTPases. The Rho family of GTPases are critical regulators of spine structure and plasticity (see Asrar and Jia, this issue). Since the regulation of the actin cytoskeleton (see Okada and Soderling, Lin and Webb, Pontrello and Ethell, this issue) and more recently, the microtubule network (see $\mathrm{Gu}$ and Zheng, this issue), have been strongly implicated in spine morphogenesis, it is possible that other genes may influence spine structure via these pathways.

Although considerable progress has been made in identifying genes that regulate synaptic structure, significant gaps exist in our knowledge of how aberrations in their function are translated into alterations in neural networks and ultimately higher order cognitive functions. The advances in genomic mining and manipulation, proteomic technology and imaging technology should provide us with the myriad of tools that are necessary to bridge this gap. This knowledge is vital to both enhance our understanding of the basic processes that guide our learning abilities and design therapeutic approaches to combat cognitive decline in a wide variety of neurological disorders, including mental retardations.

\section{ACKNOWLEDGEMENTS}

I would like to thank Drs. Louis F Reichardt (University of California, San Francisco), Lucas Pozzo-Miller (University of Alabama, Birmingham), Claudia Bagni (Catholic University of Leuven, Belgium), Linda Van Aelst (Cold Spring Harbor Laboratory) and Alan Horwitz (University of Virginia, Charlottesville) for their comments on the manuscript. I would also like to thank Dr. Gerard Beaudoin for the EM image of the synapse in Fig. (1).

\section{REFERENCES}

[1] Fiala JC, Spacek J, Harris KM. Dendritic spine pathology: cause or consequence of neurological disorders? Brain Res Brain Res Rev 2002; 39(1): 29-54.

[2] Chechlacz M, Gleeson JG. Is mental retardation a defect of synapse structure and function? Pediatr Neurol 2003; 29(1): 11-7.

[3] Kaufmann WE, Moser HW. Dendritic anomalies in disorders associated with mental retardation. Cereb Cortex 200; 10(10): 981-91.

[4] Ropers HH. X-linked mental retardation: many genes for a complex disorder. Curr Opin Genet Dev 2006; 16(3): 260-9.

[5] Tarpey PS, Smith R, Pleasance E, et al. A systematic, large-scale resequencing screen of X-chromosome coding exons in mental retardation. Nat Genet 2009; 41(5): 535-43.

[6] Yoshihara Y, De Roo M, Muller D. Dendritic spine formation and stabilization. Curr Opin Neurobiol 2009; 19(2); 146-53.

[7] Nagerl UV, Eberhorn N, Cambridge SB, Bonhoeffer T. Bidirectional activity-dependent morphological plasticity in hippocampal neurons. Neuron 2004; 44(5): 759-67.

[8] Irwin SA, Galvez R, Greenough WT. Dendritic spine structural anomalies in fragile-X mental retardation syndrome. Cereb Cortex 2000; 10(10): 1038-44.

[9] Yang Y, Wang XB, Frerking M, Zhou Q. Spine expansion and stabilization associated with long-term potentiation. J Neurosci 2008; 28(22): 5740-51.

[10] Segal M. Dendritic spines and long-term plasticity. Nat Rev Neurosci $2005 ; 6(4)$ : 277-84.

[11] Zhou Q, Homma KJ, Poo MM. Shrinkage of dendritic spines associated with long-term depression of hippocampal synapses. Neuron 2004; 44(5): 749-57.

[12] Spruston N. Pyramidal neurons: dendritic structure and synaptic integration. Nat Rev Neurosci 2008; 9(3): 206-21.

[13] Nakayama AY, Harms MB, Luo L. Small GTPases Rac and Rho in the maintenance of dendritic spines and branches in hippocampal pyramidal neurons. J Neurosci 2000; 20(14): 5329-38.

[14] Bonhoeffer T, Yuste R. Spine motility. Phenomenology, mechanisms, and function. Neuron 2002; 35(6): 1019-27.

[15] Sweatt JD. Mitogen-activated protein kinases in synaptic plasticity and memory. Curr Opin Neurobiol 2004; 14(3): 311-7.

[16] Tada T, Sheng M. Molecular mechanisms of dendritic spine morphogenesis. Curr Opin Neurobiol 2006; 16(1): 95-101.

[17] Arikkath J. Regulation of dendrite and spine morphogenesis and plasticity by catenins. Mol Neurobiol 2009; 40(1): 46-54.

[18] Arikkath J, Reichardt LF. Cadherins and catenins at synapses: roles in synaptogenesis and synaptic plasticity. Trends Neurosci 2008; 31(9): 487-94.

[19] Ethell IM, Irie F, Kalo MS, Couchman JR, Pasquale EB, Yamaguchi Y. EphB/syndecan-2 signaling in dendritic spine morphogenesis. Neuron 2001; 31(6): 1001-13.

[20] Hotulainen P, Llano O, Smirnov S, et al. Defining mechanisms of actin polymerization and depolymerization during dendritic spine morphogenesis. J Cell Biol 2009; 185(2): 323-39.

[21] Billuart P, Bienvenu T, Ronce N, et al. Oligophrenin-1 encodes a rhoGAP protein involved in X-linked mental retardation. Nature 1998; 392(6679): 923-6.

[22] Bergmann C, Zerres K, Senderek J, et al. Oligophrenin 1 (OPHN1) gene mutation causes syndromic X-linked mental retardation with epilepsy, rostral ventricular enlargement and cerebellar hypoplasia. Brain 2003; 126(Pt 7): 1537-44.

[23] Newey SE, Velamoor V, Govek EE, Van Aelst L. Rho GTPases, dendritic structure, and mental retardation. J Neurobiol 2005; 64(1): 58-74

[24] Govek EE, Newey SE, Akerman CJ, et al. The X-linked mental retardation protein oligophrenin-1 is required for dendritic spine morphogenesis. Nat Neurosci 2004; 7(4): 364-72.

[25] Bedeschi MF, Novelli A, Bernardini L, et al. Association of syndromic mental retardation with an Xq12q13.1 duplication encompassing the oligophrenin 1 gene. Am J Med Genet A 2008; 146A(13): 1718-24.

[26] Menten B, Buysse K, Vermeulen S, et al. Report of a female patient with mental retardation and tall stature due to a chromosomal rearrangement disrupting the OPHN1 gene on Xq12. Eur J Med Genet 2007; 50(6): 446-54.

[27] Zanni G, Saillour Y, Nagara M, et al. Oligophrenin 1 mutations frequently cause $\mathrm{X}$-linked mental retardation with cerebellar hypoplasia. Neurology 2005; 65(9): 1364-9. 
[28] Khelfaoui M, Denis C, van Galen E, et al. Loss of X-linked mental retardation gene oligophrenin 1 in mice impairs spatial memory and leads to ventricular enlargement and dendritic spine immaturity. J Neurosci 2007; 27(35): 9439-50.

[29] Nadif KN, Nakano-Kobayashi A, Malinow R, Li B, Van Aelst L. The Rho-linked mental retardation protein oligophrenin-1 controls synapse maturation and plasticity by stabilizing AMPA receptors. Genes Dev 2009; 23(11): 1289-302.

[30] Khelfaoui M, Pavlowsky A, Powell AD, et al. Inhibition of RhoA pathway rescues the endocytosis defects in Oligophrenin 1 mouse model of mental retardation. Hum Mol Genet 2009; 18(14): 257583 .

[31] Kreis P, Barnier JV. PAK signalling in neuronal physiology. Cell Signal 2009; 21(3): 384-93.

[32] Bienvenu T, des Portes V, McDonell N, et al. Missense mutation in PAK3, R67C, causes X-linked nonspecific mental retardation. Am J Med Genet 2000; 93(4): 294-8.

[33] Allen KM, Gleeson JG, Bagrodia S, et al. PAK3 mutation in nonsyndromic X-linked mental retardation. Nat Genet 1998; 20(1): 2530 .

[34] Zhang H, Webb DJ, Asmussen H, Niu S, Horwitz AF. A GIT1/PIX/Rac/PAK signaling module regulates spine morphogenesis and synapse formation through MLC. J Neurosci 2005; 25(13): 3379-88.

[35] Boda B, Jourdain L, Muller D. Distinct, but compensatory roles of PAK1 and PAK3 in spine morphogenesis. Hippocampus 2008; 18(9): 857-61.

[36] Boda B, Alberi S, Nikonenko I, et al. The mental retardation protein PAK3 contributes to synapse formation and plasticity in hippocampus. J Neurosci 2004; 24(48): 10816-25.

[37] Kreis P, Thevenot E, Rousseau V, Boda B, Muller D, Barnier JV. The $\mathrm{p} 21$-activated kinase 3 implicated in mental retardation regulates spine morphogenesis through a Cdc42-dependent pathway. J Biol Chem 2007; 282(29): 21497-506.

[38] Meng J, Meng Y, Hanna A, Janus C, Jia Z. Abnormal long-lasting synaptic plasticity and cognition in mice lacking the mental retardation gene Pak3. J Neurosci 2005; 25(28): 6641-50.

[39] Hayashi ML, Choi SY, Rao BS, et al. Altered cortical synaptic morphology and impaired memory consolidation in forebrain- specific dominant-negative PAK transgenic mice. Neuron 2004; 42(5): 773-87.

[40] Kutsche K, Yntema H, Brandt A, et al. Mutations in ARHGEF6, encoding a guanine nucleotide exchange factor for Rho GTPases, in patients with X-linked mental retardation. Nat Genet 2000; 26(2): 247-50.

[41] Node-Langlois R, Muller D, Boda B. Sequential implication of the mental retardation proteins ARHGEF6 and PAK3 in spine morphogenesis. J Cell Sci 2006; 119(Pt 23): 4986-93.

[42] Husi H, Ward MA, Choudhary JS, Blackstock WP, Grant SG. Proteomic analysis of NMDA receptor-adhesion protein signaling complexes. Nat Neurosci 2000; 3(7): 661-9.

[43] Martinez-Garay I, Ballesta MJ, Oltra S, et al. Intronic L1 insertion and F268S, novel mutations in RPS6KA3 (RSK2) causing CoffinLowry syndrome. Clin Genet 2003; 64(6): 491-6.

[44] Marques PP, Heron D, Hanauer A. The first large duplication of the RSK2 gene identified in a Coffin-Lowry syndrome patient. Hum Genet 2007; 122(5): 541-3.

[45] Delaunoy J, Abidi F, Zeniou M, et al. Mutations in the X-linked RSK2 gene (RPS6KA3) in patients with Coffin-Lowry syndrome. Hum Mutat 2001; 17(2): 103-16.

[46] Zeniou-Meyer M, Liu Y, Begle A, et al. The Coffin-Lowry syndrome-associated protein RSK2 is implicated in calcium-regulated exocytosis through the regulation of PLD1. Proc Natl Acad Sci USA 2008; 105(24): 8434-9.

[47] Zeniou-Meyer M, Begle A, Bader MF, Vitale N. The Coffin-Lowry syndrome-associated protein RSK2 controls neuroendocrine secretion through the regulation of phospholipase D1 at the exocytotic sites. Ann N Y Acad Sci 2009; 1152: 201-8.

[48] Thomas GM, Rumbaugh GR, Harrar DB, Huganir RL. Ribosomal S6 kinase 2 interacts with and phosphorylates PDZ domaincontaining proteins and regulates AMPA receptor transmission. Proc Natl Acad Sci USA 2005; 102(42): 15006-11.

[49] Steiner P, Higley MJ, Xu W, Czervionke BL, Malenka RC, Sabatini BL. Destabilization of the postsynaptic density by PSD-95 serine 73 phosphorylation inhibits spine growth and synaptic plasticity. Neuron 2008; 60(5): 788-802.
[50] Chao HW, Hong CJ, Huang TN, Lin YL, Hsueh YP. SUMOylation of the MAGUK protein CASK regulates dendritic spinogenesis. J Cell Biol 2008; 182(1): 141-55.

[51] Poirier R, Jacquot S, Vaillend C, et al. Deletion of the CoffinLowry syndrome gene Rsk2 in mice is associated with impaired spatial learning and reduced control of exploratory behavior. Behav Genet 2007; 37(1): 31-50.

[52] D'Adamo P, Menegon A, Lo Nigro C, et al. Mutations in GDI1 are responsible for X-linked non-specific mental retardation. Nat Genet 1998; 19(2): 134-9.

[53] D'Adamo P, Welzl H, Papadimitriou S, et al. Deletion of the mental retardation gene Gdil impairs associative memory and alters social behavior in mice. Hum Mol Genet 2002; 11(21): 2567-80.

[54] Bianchi V, Farisello P, Baldelli P, et al. Cognitive impairment in Gdil-deficient mice is associated with altered synaptic vesicle pools and short-term synaptic plasticity, and can be corrected by appropriate learning training. Hum Mol Genet 2009; 18(1): 105-17.

[55] Nakano-Kobayashi A, Kasri NN, Newey SE, Van Aelst L. The Rho-linked mental retardation protein OPHN1 controls synaptic vesicle endocytosis via endophilin A1. Curr Biol 2009; 19(13); 1133-9.

[56] Chahrour M, Jung SY, Shaw C, et al. MeCP2, a key contributor to neurological disease, activates and represses transcription. Science 2008; 320(5880): 1224-9.

[57] Cohen DR, Matarazzo V, Palmer AM, et al. Expression of MeCP2 in olfactory receptor neurons is developmentally regulated and occurs before synaptogenesis. Mol Cell Neurosci 2003; 22(4): 41729.

[58] Amir RE, Van den Veyver IB, Wan M, Tran CQ, Francke U, Zoghbi HY. Rett syndrome is caused by mutations in X-linked MECP2, encoding methyl-CpG-binding protein 2. Nat Genet 1999; 23(2): 185-8.

[59] Belichenko PV, Oldfors A, Hagberg B, Dahlstrom A. Rett syndrome: 3-D confocal microscopy of cortical pyramidal dendrites and afferents. Neuroreport 1994; 5(12): 1509-13.

[60] Chapleau CA, Calfa GD, Lane MC, et al. Dendritic spine pathologies in hippocampal pyramidal neurons from Rett syndrome brain and after expression of Rett-associated MECP2 mutations. Neurobiol Dis 2009.

[61] Belichenko PV, Hagberg B, Dahlstrom A. Morphological study of neocortical areas in Rett syndrome. Acta Neuropathol 1997; 93(1): 50-61.

[62] Cornford ME, Philippart M, Jacobs B, Scheibel AB, Vinters HV. Neuropathology of Rett syndrome: case report with neuronal and mitochondrial abnormalities in the brain. J Child Neurol 1994; 9(4): 424-31.

[63] Chen RZ, Akbarian S, Tudor M, Jaenisch R. Deficiency of methylCpG binding protein-2 in CNS neurons results in a Rett-like phenotype in mice. Nat Genet 2001; 27(3): 327-31.

[64] Guy J, Hendrich B, Holmes M, Martin JE, Bird A. A mouse Mecp2-null mutation causes neurological symptoms that mimic Rett syndrome. Nat Genet 2001; 27(3): 322-6.

[65] Jordan C, Li HH, Kwan HC, Francke U. Cerebellar gene expression profiles of mouse models for Rett syndrome reveal novel MeCP2 targets. BMC Med Genet 2007; 8: 36.

[66] Asaka Y, Jugloff DG, Zhang L, Eubanks JH, Fitzsimonds RM. Hippocampal synaptic plasticity is impaired in the Mecp2-null mouse model of Rett syndrome. Neurobiol Dis 2006; 21(1): 21727.

[67] Belichenko PV, Wright EE, Belichenko NP, et al. Widespread changes in dendritic and axonal morphology in Mecp2-mutant mouse models of Rett syndrome: evidence for disruption of neuronal networks. J Comp Neurol 2009; 514(3): 240-58.

[68] Kishi N, Macklis JD. MECP2 is progressively expressed in postmigratory neurons and is involved in neuronal maturation rather than cell fate decisions. Mol Cell Neurosci 2004; 27(3): 306-21.

[69] Fukuda T, Itoh M, Ichikawa T, Washiyama K, Goto Y. Delayed maturation of neuronal architecture and synaptogenesis in cerebral cortex of Mecp2-deficient mice. J Neuropathol Exp Neurol 2005; 64(6): 537-44.

[70] Medrihan L, Tantalaki E, Aramuni G, et al. Early defects of GABAergic synapses in the brain stem of a MeCP2 mouse model of Rett syndrome. J Neurophysiol 2008; 99(1): 112-21.

[71] Tropea D, Giacometti E, Wilson NR, et al. Partial reversal of Rett Syndrome-like symptoms in MeCP2 mutant mice. Proc Natl Acad Sci USA 2009; 106(6): 2029-34. 
[72] Shahbazian M, Young J, Yuva-Paylor L, et al. Mice with truncated $\mathrm{MeCP} 2$ recapitulate many Rett syndrome features and display hyperacetylation of histone H3. Neuron 2002; 35(2): 243-54.

[73] Moretti P, Levenson JM, Battaglia F, et al. Learning and memory and synaptic plasticity are impaired in a mouse model of Rett syndrome. J Neurosci 2006; 26(1): 319-27.

[74] Collins AL, Levenson JM, Vilaythong AP, et al. Mild overexpression of MeCP2 causes a progressive neurological disorder in mice. Hum Mol Genet 2004; 13(21): 2679-89.

[75] Chao HT, Zoghbi HY, Rosenmund C. MeCP2 controls excitatory synaptic strength by regulating glutamatergic synapse number. Neuron 2007; 56(1): 58-65.

[76] Nelson ED, Kavalali ET, Monteggia LM. MeCP2-dependent transcriptional repression regulates excitatory neurotransmission. Curr Biol 2006; 16(7): 710-6.

[77] Rao A, Cha EM, Craig AM. Mismatched appositions of presynaptic and postsynaptic components in isolated hippocampal neurons. J Neurosci 2000; 20(22): 8344-53.

[78] Liu H, Dean C, Arthur CP, Dong M, Chapman ER. Autapses and networks of hippocampal neurons exhibit distinct synaptic transmission phenotypes in the absence of synaptotagmin I. J Neurosci 2009; 29(23): 7395-403.

[79] Larimore JL, Chapleau CA, Kudo S, Theibert A, Percy AK, PozzoMiller L. Bdnf overexpression in hippocampal neurons prevents dendritic atrophy caused by Rett-associated MECP2 mutations. Neurobiol Dis 2009; 34(2): 199-211.

[80] Zhou Z, Hong EJ, Cohen S, et al. Brain-specific phosphorylation of $\mathrm{MeCP} 2$ regulates activity-dependent Bdnf transcription, dendritic growth, and spine maturation. Neuron 2006 ; 52(2): 255-69.

[81] An JJ, Gharami K, Liao GY, et al. Distinct role of long 3' UTR BDNF mRNA in spine morphology and synaptic plasticity in hippocampal neurons. Cell 2008; 134(1): 175-87.

[82] Tyler WJ, Pozzo-Miller LD. BDNF enhances quantal neurotransmitter release and increases the number of docked vesicles at the active zones of hippocampal excitatory synapses. J Neurosci 2001; 21(12): 4249-58.

[83] Ben-Shachar S, Chahrour M, Thaller C, Shaw CA, Zoghbi HY. Mouse models of MeCP2 disorders share gene expression changes in the cerebellum and hypothalamus. Hum Mol Genet 2009; 18(13): 2431-42.

[84] Chen WG, Chang Q, Lin Y, et al. Derepression of BDNF transcription involves calcium-dependent phosphorylation of $\mathrm{MeCP} 2$. Science 2003; 302(5646): 885-9.

[85] Martinowich K, Hattori D, Wu H, et al. DNA methylation-related chromatin remodeling in activity-dependent BDNF gene regulation. Science 2003; 302(5646): 890-3.

[86] Deng V, Matagne V, Banine F, et al. FXYD1 is an MeCP2 target gene overexpressed in the brains of Rett syndrome patients and Mecp2-null mice. Hum Mol Genet 2007; 16(6): 640-50.

[87] Verkerk AJ, Pieretti M, Sutcliffe JS, et al. Identification of a gene (FMR-1) containing a CGG repeat coincident with a breakpoint cluster region exhibiting length variation in fragile $\mathrm{X}$ syndrome. Cell 1991; 65(5): 905-14.

[88] O'Donnell WT, Warren ST. A decade of molecular studies of fragile X syndrome. Annu Rev Neurosci 2002; 25: 315-38.

[89] Napoli I, Mercaldo V, Boyl PP, et al. The fragile X syndrome protein represses activity-dependent translation through CYFIP1, a new 4E-BP. Cell 2008; 134(6): 1042-54.

[90] Bassell GJ, Warren ST. Fragile X syndrome: loss of local mRNA regulation alters synaptic development and function. Neuron 2008; 60(2): 201-14.

[91] Bechara EG, Didiot MC, Melko M, et al. A novel function for fragile $\mathrm{X}$ mental retardation protein in translational activation. PLoS Biol 2009; 7(1): e16.

[92] Zalfa F, Eleuteri B, Dickson KS, et al. A new function for the fragile $\mathrm{X}$ mental retardation protein in regulation of PSD-95 mRNA stability. Nat Neurosci 2007; 10(5): 578-87.

[93] Antar LN, Afroz R, Dictenberg JB, Carroll RC, Bassell GJ. Metabotropic glutamate receptor activation regulates fragile $\mathrm{x}$ mental retardation protein and FMR1 mRNA localization differentially in dendrites and at synapses. J Neurosci 2004; 24(11): 2648-55.

[94] Price TJ, Flores CM, Cervero F, Hargreaves KM. The RNA binding and transport proteins staufen and fragile $\mathrm{X}$ mental retardation protein are expressed by rat primary afferent neurons and localize to peripheral and central axons. Neuroscience 2006; 141(4): 210716.
[95] Antar LN, Li C, Zhang H, Carroll RC, Bassell GJ. Local functions for FMRP in axon growth cone motility and activity-dependent regulation of filopodia and spine synapses. Mol Cell Neurosci 2006; 32(1-2): 37-48.

[96] Ferrari F, Mercaldo V, Piccoli G, et al. The fragile X mental retardation protein-RNP granules show an mGluR-dependent localization in the post-synaptic spines. Mol Cell Neurosci 2007; 34(3): 343-54.

[97] Zalfa F, Achsel T, Bagni C. mRNPs, polysomes or granules: FMRP in neuronal protein synthesis. Curr Opin Neurobiol 2006; 16(3): 265-9.

[98] Ronesi JA, Huber KM. Metabotropic glutamate receptors and fragile $\mathrm{x}$ mental retardation protein: partners in translational regulation at the synapse. Sci Signal 2008; 1(5): pe6.

[99] Rudelli RD, Brown WT, Wisniewski K, et al. Adult fragile X syndrome. Clinico-neuropathologic findings. Acta Neuropathol 1985; 67(3-4): 289-95.

[100] Hinton VJ, Brown WT, Wisniewski K, Rudelli RD. Analysis of neocortex in three males with the fragile X syndrome. Am J Med Genet 1991; 41(3): 289-94.

[101] Irwin SA, Patel B, Idupulapati M, et al. Abnormal dendritic spine characteristics in the temporal and visual cortices of patients with fragile-X syndrome: a quantitative examination. Am J Med Genet 2001; 98(2): 161-7.

[102] Bagni C, Greenough WT. From mRNP trafficking to spine dysmorphogenesis: the roots of fragile X syndrome. Nat Rev Neurosci 2005; 6(5): 376-87.

[103] Comery TA, Harris JB, Willems PJ, et al. Abnormal dendritic spines in fragile $\mathrm{X}$ knockout mice: maturation and pruning deficits. Proc Natl Acad Sci USA 1997; 94(10): 5401-4.

[104] Restivo L, Ferrari F, Passino E, et al. Enriched environment promotes behavioral and morphological recovery in a mouse model for the fragile X syndrome. Proc Natl Acad Sci USA 2005; 102(32): 11557-62.

[105] Grossman AW, Elisseou NM, McKinney BC, Greenough WT. Hippocampal pyramidal cells in adult Fmrl knockout mice exhibit an immature-appearing profile of dendritic spines. Brain Res 2006; 1084(1): 158-64.

[106] Koekkoek SK, Yamaguchi K, Milojkovic BA, et al. Deletion of FMR1 in Purkinje cells enhances parallel fiber LTD, enlarges spines, and attenuates cerebellar eyelid conditioning in Fragile X syndrome. Neuron 2005; 47(3): 339-52.

[107] Nimchinsky EA, Oberlander AM, Svoboda K. Abnormal development of dendritic spines in FMR1 knock-out mice. J Neurosci 2001; 21(14): 5139-46.

[108] Braun K, Segal M. FMRP involvement in formation of synapses among cultured hippocampal neurons. Cereb Cortex 2000; 10(10): 1045-52.

[109] Pfeiffer BE, Huber KM. Fragile X mental retardation protein induces synapse loss through acute postsynaptic translational regulation. J Neurosci 2007; 27(12): 3120-30.

[110] de Vrij FM, Levenga J, van der Linde HC, et al. Rescue of behavioral phenotype and neuronal protrusion morphology in Fmr1 KO mice. Neurobiol Dis 2008; 31(1): 127-32.

[111] Dictenberg JB, Swanger SA, Antar LN, Singer RH, Bassell GJ. A direct role for FMRP in activity-dependent dendritic mRNA transport links filopodial-spine morphogenesis to fragile $\mathrm{X}$ syndrome Dev Cell 2008; 14(6): 926-39.

[112] Bilousova TV, Dansie L, Ngo M, et al. Minocycline promotes dendritic spine maturation and improves behavioural performance in the fragile X mouse model. J Med Genet 2009; 46(2): 94-102.

[113] Li J, Pelletier MR, Perez Velazquez JL, Carlen PL. Reduced cortical synaptic plasticity and GluR1 expression associated with fragile $\mathrm{X}$ mental retardation protein deficiency. Mol Cell Neurosci 2002; 19(2): 138-51.

[114] Godfraind JM, Reyniers E, De Boulle K, et al. Long-term potentiation in the hippocampus of fragile $\mathrm{X}$ knockout mice. Am J Med Genet 1996; 64(2): 246-51.

[115] Lauterborn JC, Rex CS, Kramar E, et al. Brain-derived neurotrophic factor rescues synaptic plasticity in a mouse model of fragile X syndrome. J Neurosci 2007; 27(40): 10685-94.

[116] Huber KM, Gallagher SM, Warren ST, Bear MF. Altered synaptic plasticity in a mouse model of fragile $\mathrm{X}$ mental retardation. Proc Natl Acad Sci USA 2002; 99(11): 7746-50.

[117] Bear MF, Huber KM, Warren ST. The mGluR theory of fragile X mental retardation. Trends Neurosci 2004; 27(7): 370-7. 
[118] Pilpel Y, Kolleker A, Berberich S, et al. Synaptic ionotropic glutamate receptors and plasticity are developmentally altered in the CA1 field of Fmr1 knockout mice. J Physiol 2009; 587(Pt 4): 787804.

[119] Centonze D, Rossi S, Mercaldo V, et al. Abnormal striatal GABA transmission in the mouse model for the fragile $\mathrm{X}$ syndrome. Biol Psychiatry 2008; 63(10): 963-73.

[120] Hanson JE, Madison DV. Presynaptic FMR1 genotype influences the degree of synaptic connectivity in a mosaic mouse model of fragile X syndrome. J Neurosci 2007; 27(15): 4014-8.

[121] Dolen G, Osterweil E, Rao BS, et al. Correction of fragile X syndrome in mice. Neuron 2007; 56(6): 955-62.

[122] Zeier Z, Kumar A, Bodhinathan K, Feller JA, Foster TC, Bloom DC. Fragile $\mathrm{X}$ mental retardation protein replacement restores hippocampal synaptic function in a mouse model of fragile $\mathrm{X}$ syndrome. Gene Ther 2009; 16: 1222-9.

[123] Tarpey PS, Raymond FL, Nguyen LS, et al. Mutations in UPF3B, a member of the nonsense-mediated mRNA decay complex, cause syndromic and nonsyndromic mental retardation. Nat Genet 2007; 39(9): 1127-33.

[124] Laumonnier F, Shoubridge C, Antar C, et al. Mutations of the UPF3B gene, which encodes a protein widely expressed in neurons, are associated with nonspecific mental retardation with or without autism. Mol Psychiatry 2009; doi:10.1038/mp.2009.14.

[125] Lise MF, El-Husseini A. The neuroligin and neurexin families: from structure to function at the synapse. Cell Mol Life Sci 2006; 63(16): 1833-49.

[126] Song JY, Ichtchenko K, Sudhof TC, Brose N. Neuroligin 1 is a postsynaptic cell-adhesion molecule of excitatory synapses. Proc Natl Acad Sci USA 1999; 96(3): 1100-5.

[127] Varoqueaux F, Jamain S, Brose N. Neuroligin 2 is exclusively localized to inhibitory synapses. Eur J Cell Biol 2004; 83(9): 44956.
[128] Jamain S, Radyushkin K, Hammerschmidt K, et al. Reduced social interaction and ultrasonic communication in a mouse model of monogenic heritable autism. Proc Natl Acad Sci USA 2008; 105(5): 1710-5.

[129] Varoqueaux F, Aramuni G, Rawson RL, et al. Neuroligins determine synapse maturation and function. Neuron 2006; 51(6): 74154.

[130] Laumonnier F, Bonnet-Brilhault F, Gomot M, et al. X-linked mental retardation and autism are associated with a mutation in the NLGN4 gene, a member of the neuroligin family. Am J Hum Genet 2004; 74(3): 552-7.

[131] Daoud H, Bonnet-Brilhault F, Vedrine S, et al. Autism and nonsyndromic mental retardation associated with a de novo mutation in the NLGN4X gene promoter causing an increased expression level. Biol Psychiatry 2009; (in press).

[132] Sudhof TC. Neuroligins and neurexins link synaptic function to cognitive disease. Nature 2008; 455(7215): 903-11.

[133] Gecz J, Gedeon AK, Sutherland GR, Mulley JC. Identification of the gene FMR2, associated with FRAXE mental retardation. Nat Genet 1996; 13(1): 105-8.

[134] Bonnet C, Leheup B, Beri M, Philippe C, Gregoire MJ, Jonveaux P. Aberrant GRIA3 transcripts with multi-exon duplications in a family with X-linked mental retardation. Am J Med Genet A 2009; 149A(6): 1280-9.

[135] Tabolacci E, Pomponi MG, Pietrobono R, Terracciano A, Chiurazzi P, Neri G. A truncating mutation in the IL1RAPL1 gene is responsible for X-linked mental retardation in the MRX21 family. Am J Med Genet A 2006; 140(5): 482-7.

[136] Tarpey P, Parnau J, Blow M, et al. Mutations in the DLG3 gene cause nonsyndromic X-linked mental retardation. Am J Hum Genet 2004; 75(2): 318-24.

(C) Jyothi Arikkath; Licensee Bentham Open .

This is an open access article licensed under the terms of the Creative Commons Attribution Non-Commercial License (http://creativecommons.org/licenses/by-nc/3.0/) which permits unrestricted, non-commercial use, distribution and reproduction in any medium, provided the work is properly cited. 